\title{
Where are the Jews in Post-Holocaust Cluj (Kolozsvar)
}

\author{
Gabriel Mayer ${ }^{1}$ \\ ${ }^{1}$ Gabriel Mayer, Head Historian-Martef Hashoah Museum, Jerusalem; Graduate Affiliate University of Haifa, Israel. \\ Correspondence: Gabriel Mayer, Post Box 400, Nahariya 2240228, Israel.
}

Received: July 24, 2016

Accepted: August 8, 2016

Available online: August 11, 2016

doi:10.11114/ijsss.v4i9.1801

URL: http://dx.doi.org/10.11114/ijsss.v4i9.1801

\begin{abstract}
The relocation of Jews after the Holocaust depended on many factors, and as time passed many survivors did not return to their previous homes, or decided to relocate shortly after returning. This paper examines the Jews of Cluj (Kolozsvar) and by extension Transylvania and Romania during the months and years following the Holocaust. Romania by various estimates, depending on whether the population counts are Romanian or Hungarian, at one time had a Jewish population upward of 700,000 yet today that number is fewer than 10,000. What happened, how and why is explored in this work.
\end{abstract}

Keywords: Holocaust; Hungarian Jews; Romanian Jews; post-Holocaust Jewish population migrations

\section{Introduction}

With the end of WWII and the Holocaust over, populations were shifting wildly throughout Europe. The most unstable and violently disturbed group was that of the Jews, who after horrifying loss of life and property were now cast into the future without a homeland.

Who was a Jew? Who claimed to be a Jew? And, what lies behind the claiming of personhood in postwar Europe? For Jews it was not uncommon for those without any religious practices before the Holocaust to become very religious and conversely some who had been religious, now turned their back on G_d.

This work is aimed at examining the shifting nature of Jewish identity in the days after the end of the war. The primary focus is centered on Cluj-now a part of Romania-and what happened in the time leading up to the events in Kolozsvar-as it was known in the days of Hungarian dominion. By extension, some of the discussion will extend into Northern Transylvania-the territory that experienced the most severe effects of the Holocaust during 1942-1944, and to some degree, examine the Hungarian Holocaust's effects on population and identity of Jews. How did the rise of Communist dominance in Eastern Europe and the hope for an Israeli state in Palestine, affect local considerations?

While prior to the 1948 formation of the state of Israel, the notion of a Jewish homeland encouraged Zionist aspirations; the vast majority of Jews knew little about the choices of statehood and personhood; identity was a matter of survival more than anything else.

In the aftermath of the days after, new possibilities and opportunities became available, although sometimes the new option was to deny one's Jewish origins; after all, given the opportunity to do so and looking at what just happened, could one blame a person who chose to de-Judify their identity?

Of note is that fractionally speaking, the numbers of Jews involved in such an enterprise are far lower than the number of Jews living prior to the Holocaust. With over $80 \%$ of Northern Transylvanian Jews murdered, ${ }^{1}$ this would seem an obvious statement, however the distinction is a focus point for the how and why the survivors stayed alive. Even while prisoner \#174517, Primo Levi, has famously attributed survival to luck, ${ }^{2}$ in reality-as will become clear in the discussion to follow-there would be many other factors to consider. And these are the very factors that would determine what happened to these surviving Jews.

\section{Geopolitical Factors Entering into War and During the Holocaust}

Cluj, Kolozsvar in Hungarian, is the capital of the region known as Northern Transylvania, from hereon referred to as

\footnotetext{
1 (Braham 1983, pasim); (Braham 1994, pasim)

2 (Roth 1980) The author Phillip Roth maintained a long friendship with Primo Levi, and interviewed him several times both on and off the record. See also: Interview (Levi 1996, pp. 175-187)
} 
Transylvania, or Erdely in Hungarian. This region is populated by two major ethnic groups: Hungarian and Romanian and, much to consternation of one or another of these groups, has changed hands between two countries: Romania and Hungary, several times in the $20^{\text {th }}$ century. The title of Holly Case's excellent study of this historical period, Between States ${ }^{3}$ conveys exactly the headlining issues that would affect the Jewish population's future, especially after the end of WWII. According to Case, "The events of the Holocaust in Hungary and Romania were heavily influenced by the fact that the Jews were not the primary policy preoccupation in these states either before or during the war. Instead, the "Jewish Question" was frequently viewed in light of its relationship to territorial matters, and for that reason Hungarian and Romanian policy vis-à-vis the Jews was shockingly inconsistent." ${ }^{4}$ Nonetheless, the invasion of Hungary by Nazi Germany on March 19,1944 suddenly launched the fate of these Jews-populating Cluj and Transylvania- into a similar tragedy. The understanding of the catastrophic events, which transpired for the Jews of Kolozsvar in the spring of 1944, is draped across two time-lines. A general and several decades long perspective points to an assimilated Jewry identifying itself in a Magyarized (Hungarian) fashion and clinging to this notion despite warning signals, because of a maintained sense of security, which may seem odd in hindsight, but was easily understandable in a contemporaneous setting. The second, much shorter, brutal, and fatefully murderous turn of events rolled out during nine weeks from March 19 -May 25, when the first trains started to depart to Auschwitz.

As can be seen in Hungarian Jewish history, a much heralded and unparalleled set of events- assimilation- propelled the Jews of Hungary to economic and social success, which, even after Trianon and Romania's annexation of Transylvania remained as a bedrock of identity for the Koloszvar Jews, much as it did in the rest of Northern Transylvania. According to the 1940 Second Vienna award Transylvania (and Kolozsvar) reverted to Hungary and by 1941, the time of promulgation of the Third Jewish Laws, the fate of Kolozsvar's Jews was in the hands of the Hungarian political system.

It is a fact that murderous rampages took place in Transylvania as early as July 1941- Kaments-Podolski- but despite wide knowledge of these massacres and brutal social and economic sanctions, the city of Kolozsvar was insulated from the most severe actions seen elsewhere. "But as harsh as these measures were, they did not shake the basic confidence of Hungarian Jews, and especially the assimilated ones, that they were not in physical danger". ${ }^{5}$ Indeed, records show that social life, schooling, intellectual functions such as art and concerts continued well into early $1944^{6}$. Furthermore, when the tide of war began to turn on the Eastern Front, the Horthy government started to relax some of the anti-Jewish measures during 1943 in what has been described as the thaw of $1943^{7}$.

By 1944 refugees and escapees from the East had arrived in Transylvania, told the populace of mass murders and catastrophes, but on the other hand even they were in disbelief when strolling through town: "They had not expected a place where there was no "yellow star" and Jews could walk about freely without fear, and could go on trips." 8 By the beginning of 1944 there were indications of the Nazis plans to invade Hungary and deport the Jews, and some have maintained that many of the leadership elite knew what was about to happen, yet they chose to share this information and direct the rescue efforts in the direction of a few in the economically, politically and religiously advantaged groups. ${ }^{9}$ It is on this background that Kolozsvar commenced the year of 1944.

While there were some indications of a hardening of Nazi attitude toward Hungarian politics (Horthy and Kallay had drawn their suspicion in 1943) no one predicted the sudden German invasion on March 19,1944- Operation Margharete was launched while Horthy was on a state visit to Hitler, his return held back for this very reason ${ }^{10}$. A fortunate irony was playing out in Romania during these times. Antonescu's fascist Romanian government was revising the policies on deportation, wisely noting that Germany would lose the war, and therefore began holding back on deportations, especially in the heartland of Romania, which bordered Transylvania. ${ }^{11}$ As events progressed, Romania, just across the border, was becoming a safe haven of sorts for Jews fleeing Transylvania

\section{Final Factors}

The fate of Jews in Cluj and Transylvania depended on several factors, which would also often influence their future

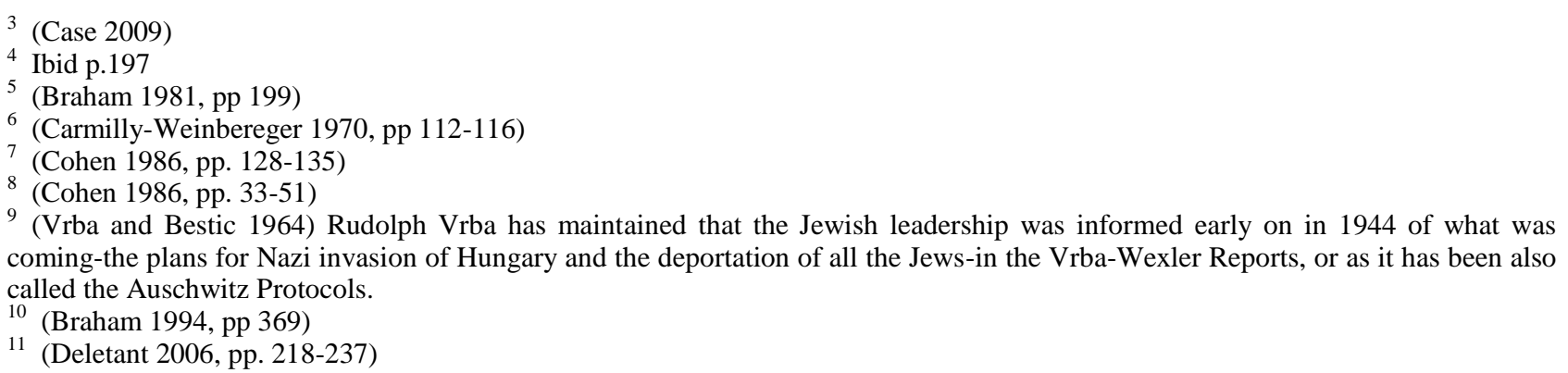


lives. Some managed to go into hiding by completely changing identities, either by apostasy, or conversion, during preceding time periods or outright fraud later on. This occurred more frequently than estimated initially, simply because the Hungarian census of 1944 missed as many as 100,000 additional Jews as far as identitfication, despite the newly released questionnaires in the middle of the census during $1944 .^{12}$

\subsection{Looking Closer}

A few detailed stories can illuminate the fact that Jews were in an unpredictable situation before, during and just after the Holocaust. While the circumstances were out of their control and often not chosen but forced, some were able to seize the occasional opportunity to evade or escape the immediate danger, while others chose to change their circumstances-relocating, or altering identity, or politically re-aligning-after return, if they managed to survive.

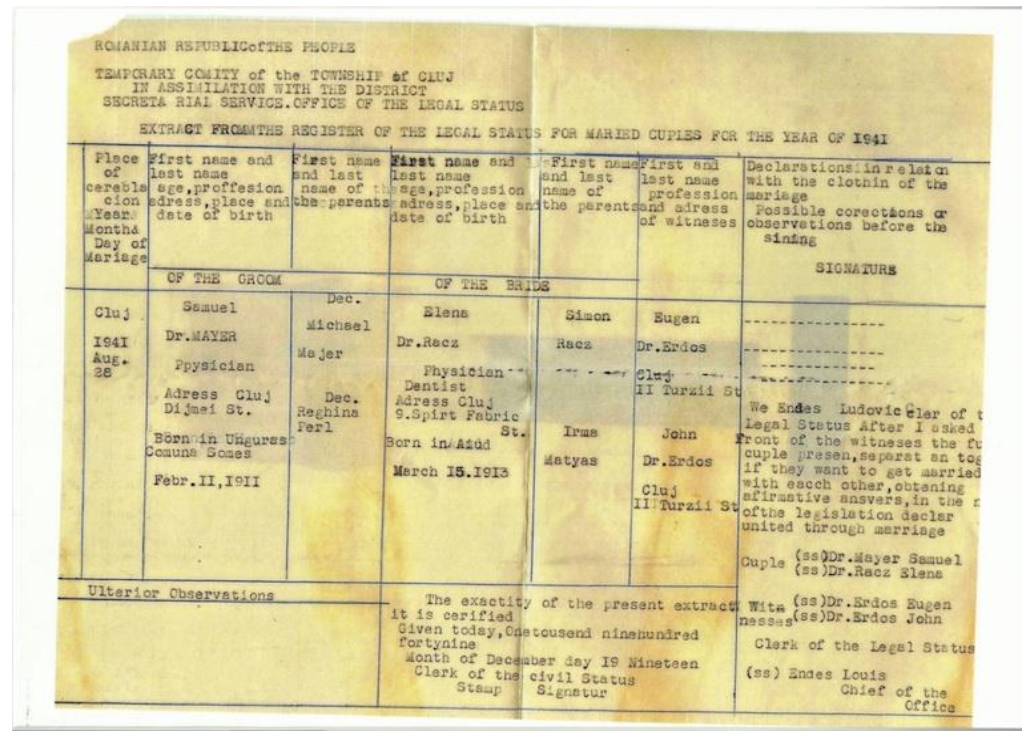

Marriage Certificate 1941

The above shows a marriage certificate dated 1941. Present in this document are four medical doctors, all graduates from Cluj Medical school, located in what was Romania in 1938; the bride related as a first cousin to the two witnesses (Drs. John and Eugen Erdos). Of note is that there were four additional Jewish classmates in the small graduating class of 1938, even under the numerous clausus rules. ${ }^{13}$ In May 1944 the woman, Dr. Ilona Mayer would be escaping the ghetto with a ten-month-old child, at first hiding in a gentile's house and then walking to safety by crossing into Romania; the groom, Dr. Samuel Mayer inducted into the Hungarian Forced Labor Force would survive the war and return home, while the two brothers wound up in Auschwitz. Only John Erdos survived and after internment in DP camp he would relocate to New York in the USA and resume medical practice. In Auschwitz he lost his wife and two children and in the DP camp he met Eva Fenichel also from Cluj and similarly losing her whole family. They would get married and after years of trying had one daughter named Karen, who would in her mid-20s commit suicide. How could such different fates befall four similar Jews living in the city of Kolozsvar? Of further interest is the fact that Samuel and Ilona Mayer chose to return to medical practice in Cluj and for some time were highly regarded academicians in the medical school. Samuel Mayer was a member of the Communist party and received a series of promotions. However, by the mid-1950s hardcore Stalinism enveloped Romanian politics and soon they were demoted and then kicked out of both the party and the medical school. Some years later they would immigrate to Italy and subsequently to the USA. ${ }^{14}$

\footnotetext{
${ }^{12}$ Fascinatingly, for many years the number of Jews in Hungary was placed at just under 800,000 and having been thus informed by no less than the doyen of Hungarian Holocaust studies-Randolph Braham-no one questioned this. It was much later that newly revised figures derived from studying the very census in discussion yielded a number near 960,000.(Mayer 2014, pp. 105-6); (Fenyo 2014). The differences are explained by subtle changes in the census forms when the third ant-Jewish laws were passed and this represents a subtlety often missed by historians who list only two sets of anti-Jewish laws.

${ }_{13}$ It is a historical fact that not all numerous clausus edicts were followed consistently (Blumstock and Braham 1981, pp. 28-32)

${ }^{14}$ (Lőwy and Schvarcz 1998, p. 291); (Mayer 2013) This interview with Peter Mayer, their eldest son, one of several, was performed in 2013. See also: (Lustigs 2014-2016) The Museum of Hungarian Speaking Jewry, in Safed Israel has proven to be a resource for multiple reference materials; it is operated by the founders Hava and Joseph Lustig and the son Ron Lustig.
} 


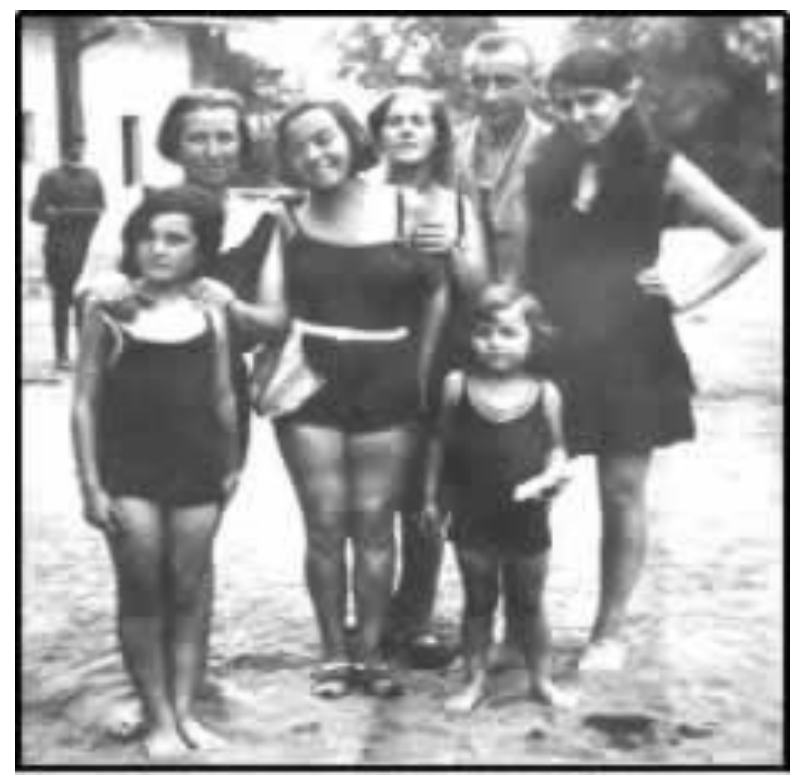

Magda Herzberger (Mozes) age 3

Magda Herzberger (Mozes) was born in Cluj and was in a loving family home until 1944.

The Mozes family, along with thousands of other Jews, was forced into the Cluj Ghetto. It was liquidated only a month later. Magda and her family were sent to Auschwitz, where most of them perished. After six weeks in Auschwitz, 18-year-old Magda was shipped to Bremen, Germany. She performed forced labor even as Allied forces bombed the city. In March 1945, Magda was transferred to the Bergen-Belsen concentration camp. Her job there was to dispose of thousands of bodies that had accumulated in and around the barracks. On April 15, 1945, she collapsed from exhaustion. Magda was near death when a liberating British soldier found her among the corpses. ${ }^{15}$ She attributes her survival partially to good fortune but adds that her background as a swimming champion in high school gave her the physical stamina to survive where others did not. ${ }^{16}$ Magda returned to Cluj late in 1945. In April 1946, she began medical school, where she met and married Eugene Herzberger. Eugene, also from Cluj and a graduate of the medical school a few years prior, owes his good fortune to escape deportation to the fact that a few months prior to March 1944 he had relocated to Romanian territory. She was admitted to medical school in 1946 under a special scholarship program granted to Jewish survivors, but this was withdrawn only seven months after she started medical school and thus she was forced to drop her studies. Fearing persecution under Communism, the Herzbergers fled Romania for Israel in 1947. The British, who severely restricted immigration to Israel, captured her ship in the Aegean Sea and brought it to Cyprus. The Herzbergers were held in a makeshift prison camp until permitted to leave for Israel in January 1949. In 1957, after nine years in Israel, the Herzbergers immigrated to the U.S.

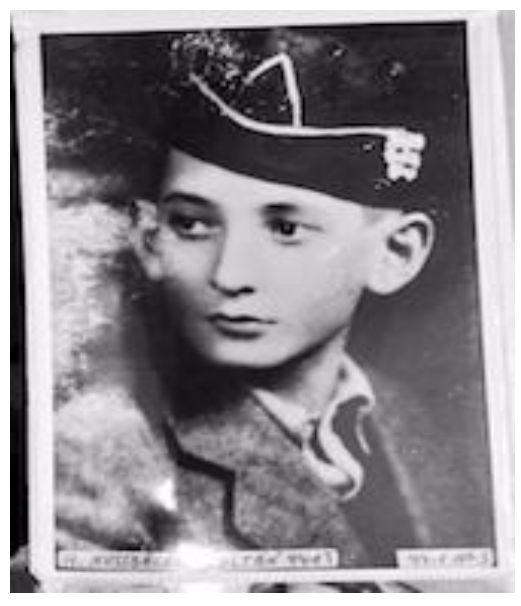

Zoltan Nussbacher in 1944, age 12, Photo taken early 1944

15 (Herzberger 2011)

16 (Herzberger 2005); Additional details were provided to the author during a series of interviews (Herzberger 2013 \& 2014). 
Zoltan Nussbacher, shown at age 12 dressed in a typical Hungarian style uniform, was 12 years old when the photo was taken, perhaps weeks before the invasion of Hungary in early 1944. The family lived in Cluj, but his older brother Dr. Erno Nussbacher had recently moved to Aiud, Romania-only $31 \mathrm{~km}$ distance from Cluj-but over the border, therefore not in Transylvania.

The rest of the family was deported and nothing was heard from them until Zoltan contacted his brother in Romania and told him he was alive and living in Israel. They never met up, because in 1957 Erno was taken-in the middle of the night, by the Securitate or secret police-to an unknown location; the family was notified seven months later that he died in an automobile accident in the mountains. ${ }^{17}$

\subsection{Special Cases and Preferential Treatment}

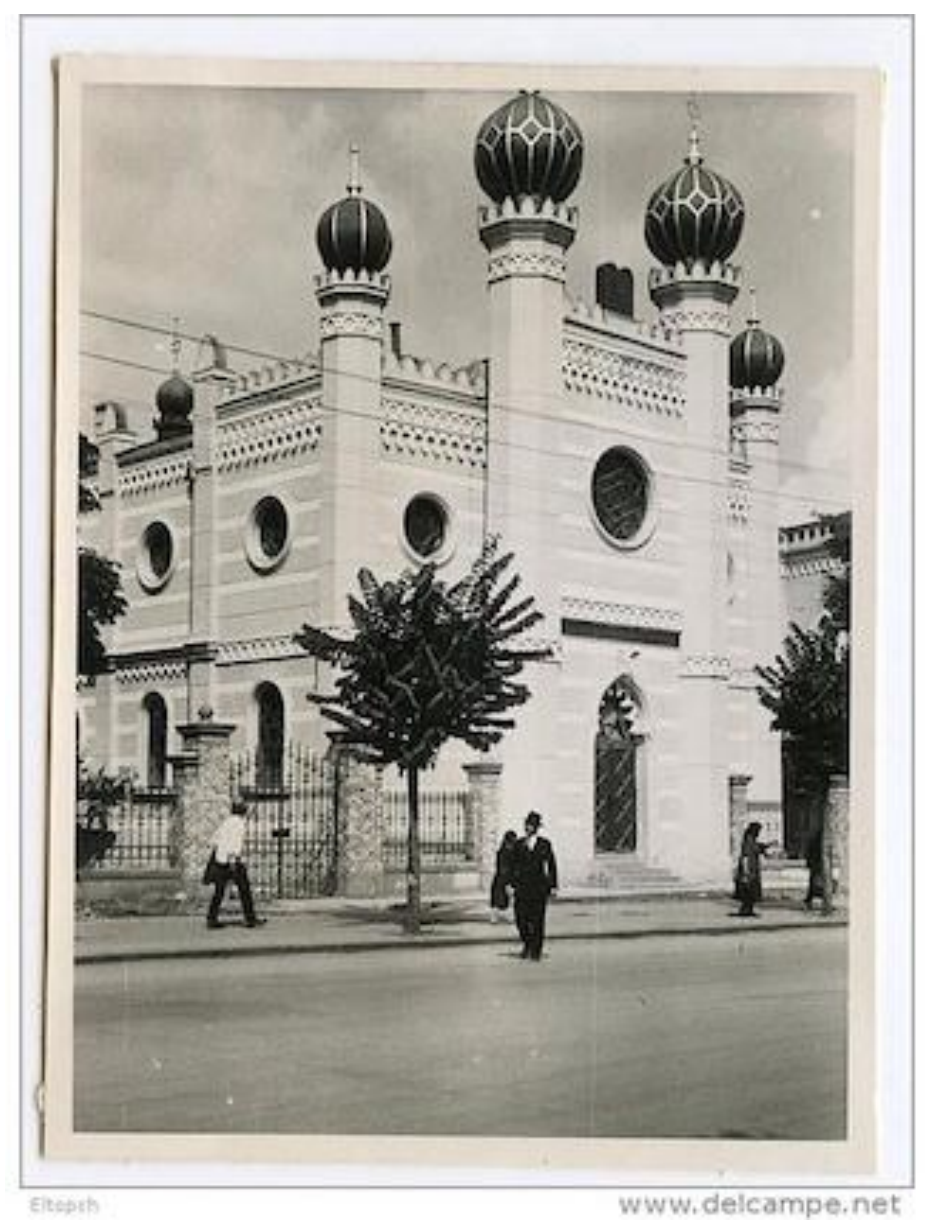

Cluj/Kolozsvar Neolog Synagogue in 1930s- destroyed in $1944^{18}$

Among those surviving the war were certain groups, composed of individuals regarded as elite, wealthy, or receiving special treatment for one reason or another.

This was not necessarily preferential in all cases. As an example we should consider members of youth movements-Halutz and Zionist Youth- who organized escape routes from Cluj to the Romanian border, on to Bucharest and thereafter via Turkey to Palestine. An estimation of those utilizing this route puts the numbers as high as 4500 , yet although passing via Cluj, it is not known how many were from the city or the nearby region. ${ }^{19}$ What is known for

\footnotetext{
17 (Nussbacher 2014,May 20); The photograph shown was located at the Museum of Hungarian Jewry in Safed, Israel and confirmed to be genuine by the niece Marta Nussbacher.

18 Rabbi Moshe Carmilly-Weinberger led the Neolog Synagogue and the community. This community represented the most assimilated group of Jews and they occupied most of the professional positions from medicine to academia and the arts. The synagogue was named the Kolozsvar Synagogue even during the 1930s when Romania was the government of record. Quite simply, this community prided itself on its Hungarian heritage, and used the Hungarian language as the first choice for speaking and writing, and while some knew Yiddish, the second choice for language was German; they all knew Romanian, but that was a last choice. Dr. Rabbi Carmilly-Weinberger, wrote all his texts and publications in Hungarian(Carmilly-Weinberger 1988).

19 (Cohen 1986, pp. 35-42); Asher Cohen is quoted at placing these numbers at 5000-7000 by Stark (Stark 2000, p. 31)
} 
certain is that virtually all of these youths eventually reached Palestine and continued to live in Israel.

There were definite efforts to rescue and preserve the lives of community leaders, especially from the Orthodox clergy. Several "deals were cut" for their safe passage via Romania onto Turkey and then Palestine, and many of these negotiations went through the hands of Dr. Wilhelm Filderman who was in Bucharest during these times. He was a lawyer by training and a Jewish community leader, but even more important he was an elected member of the Romanian Parliament, a former classmate of Marshall Ion Antonescu and trusted and held in high esteem by the Jewish community, having been elected as President of the Union of Romanian Jews and also the representative of the Joint Distribution Committee in Romania. ${ }^{20}$ Dr. Filderman was rather negatively disposed towards Communism and after the end of the war was imprisoned for 6 months and afterward made his way to France where he remained until his death in the 1960 s at age 80 .

Among the most notable out of those who were spirited out of the country through special means was Dr. Rabbi Moshe Carmilly-Weinberger, chief rabbi and head of the Neologue Jewish Community in Cluj. He was assisted in making it out of Cluj via Romania and to Bucharest and then during the summer of 1944 sailed for Palestine. Briefly imprisoned at the Atlit detention camp he eventually reached Jerusalem on July 29, 1944 and there he held a meeting with Chief Rabbi L.L.Herzog. He and his family were eventually taken to New York where he was a Professor Emeritus at Yeshiva University until his death. Of interest is that in 1990, the Babes-Bolya University in Cluj established the Dr. Moshe Carmilly Institute -still functioning-as part of the College of History and Philosophy. ${ }^{21}$ In a similar vein a number of rabbis along with their extended families received specially facilitated attention, usually through means of financial inducement, and were thus removed from harm's way prior to the start of deportations. As was sometimes the case, financial inducements could produce an occasional false set of papers allowing for emigration, most often via the Romanian corridor as a gateway to the east. Best known, and most controversial, is the case of the "Kasztner Train" whereby 1461 individuals were taken through a route that included a few weeks' sojourn in Bergen-Belsen and eventually to survival and freedom; as far as is known, none of these individuals ever returned to Hungary, or Kolozsvar. Out of the 1461, approximately 600 were from Kolozsvar. ${ }^{22}$ This case is one of outright purchase of lives for money and is well documented and has caused much debate, including a famous trial in Tel Aviv whereby Rezso Kasztner was vilified as a Nazi collaborator. Despite his ultimate legal vindication, he was subsequently assassinated in Tel Aviv while walking on the streets.

Kasztner's titular role was head of the Budapest Jewish Rescue Committee, and while much of his activities were conducted from Budapest, he was originally from Cluj and his family roots as well as most members of his extended family were in Cluj. Indeed, his father in-law, was Dr. Jozsef Fischer, the head of the Cluj Jewish council, and for this fact there was always a question of why was the populace not informed of what was about to befall them. In addition, there were several desperate attempts, in the period from early 1944 till late spring, to "purchase" Jewish lives, mostly without merit or success. ${ }^{23}$ Only the names of the rescued or saved are known and in virtually every case they would settle in Palestine or the USA, and not return to Cluj, or Hungary or Romania.

\footnotetext{
20 (Strochlitz 1943-1949, RC 2-RC 8; RC13; RC14)

21 A fascinating account of the institutes activities may be found in a review article by Gabriela Pop (Pop 2008). Over the past three years this author has had personal contact with Dr. Pop and has received additional information and introductions.

22 (Kasztner 2013, pp. 124-5) The Kasztner Report was published decades after its original writing and, perhaps understandably, years after the controversy around the case subsided. It was finally in 2006 that Professors David Bankier and Dan Michman at Yad Vashem decided to begin work on the publication from the original version written in 1946.

${ }^{23}$ (Bauer 1994, pasim) and (H.E.A.R.T. 2013): several detailed accounts have emerged about frantic efforts to save any and all that may be saved through negotiations with the Nazis, for the most part via representatives of Eichmann or Himmler.
} 


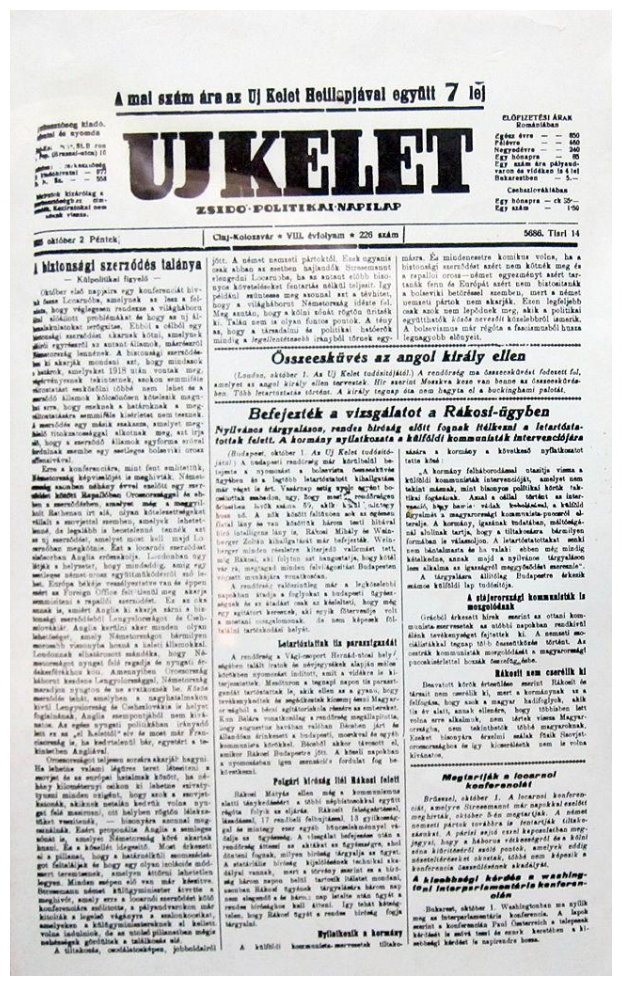

Uj Kelet (New East) front page: 5686 Tishrei (Oct 17, 1925)

The Uj Kelet (New East) was a Zionist newspaper (weekly), which appeared in the 1920s, and its chief editor was Dr. Erno Marton a prominent lawyer in the city. Published in the 1920s while Cluj was under Romanian sovereignty, its primary language was Hungarian although it did appear at various times in Romanian and Hebrew editions. Among members of its editorial board was Rezso Kasztner. The paper reappeared in Tel Aviv commencing in 1948 with Dr. Marton continuing as the editor. Dr. Marton was able to leave Cluj prior to deportations and he was among those whose path was the Romanian corridor to Bucharest and then by Turkey to Palestine. The Strochlitz Institute at Haifa University has several boxes archiving Dr. Marton's papers. It is in these archives that much of the correspondences relative to the rescue efforts in 1943-1944 are found. ${ }^{24}$

Among individual stories of survivors is the case of Andres Mehadea, who was interviewed by the author after referral by one of his childhood friends (Dr. Peter Mayer) ${ }^{25}$ He was born Andor Mihaly in the early 1940s (exact date unknown) to a Jewish family who was deported and murdered but they managed to leave their child with a local Hungarian family. He was raised as their own child and at some point his name-perhaps along with the whole family's too-was altered into a Romanianized name. He later became a lawyer and was a member of the Securitate until the 1989 Revolution. ${ }^{26} \mathrm{He}$ somehow managed to politically maneuver from his past Communist role into a successful law practice. What made this meeting and interview unusual is that he cautioned about speaking in Hungarian (except inside his home) and urged that nothing be spoken of his past, or friendships, in public. This is a singular example by an individual of carefully and purposefully shedding his Jewish Hungarian origins.

\subsection{An Overview of the Population}

In the foregoing discussion, identifying individuals and their fate as the war came to conclusion has been relatively easy. On the other hand, with the end of the war much confusion ensued and it was an opportune time for many to alter identity - personhood and nationhood-and indeed choices were made out of perceived need for survival and opportunity. Efforts to get a handle on Jews as a group and for demographic purposes were made on several occasions and published under a few isolated conditions. At the time of the Nazi occupation in March 1944 the population of Transylvania was

\footnotetext{
24 (Strochlitz 1943-1949) Additional files are located in Guide No. 4

R1-4C; III- R1-4C 1926-1947

25 (Mehadea 1991)

${ }^{26}$ In December of 1989 a revolution that began in Timisoara (Transylvania) led by the dissident bishop of Hungarian Reform Church, and whose fiery speeches from the diocese balcony fomented the crowds, resulted in the overthrow of Ceacescu's Communist dictatorship. (Bruszt and Horvath 1990)
} 
approximately 160,000 and that of Cluj was $16,800{ }^{27}$ However these numbers may be low, as in the case of Cluj many estimates place the population closer to 20,000. ${ }^{28}$ A more precise number is available for the number of deportees and for Transylvania that is estimated at $140,000{ }^{29}$ The World Jewish Congress undertook the most extensive data gathering effort in 1946. Teams of sociologists, academics and others qualified by training, were sent throughout Romania, which now was the state wherein Transylvania and Cluj now belonged. The objective was to survey the populations, assess needs as well as losses and to try to document some of the life experiences Jews underwent during these tragic times. From the start of the survey it became evident that smaller communities and villages were not amenable to surveying because of the small numbers along with the structural difficulties of carrying out meaningful population surveys in isolated localities. Final questionnaires were never tabulated by the WJC and the files went into storage, where they became especially neglected during the Communist regimes that followed and were eventually deposited by some Communist functionaries in a basement in Bucharest located along Revista Cultului Mosaic (today Realitatea Evreiasca). At this location they were exposed to several floods and finally in the past two to three decades became the property of the Federation of Jewish Communities in Romania. ${ }^{30}$ Thus for Northern Transylvania the three most surveyable locations as well as the localities with a reasonable number of records found to analyze were Cluj, Oradea and Carei (Satu Mare). Some of the information gathered in the final report has now been duplicated and dispersed in several locations outside of Romania, the most concentrated being at Yad Vashem and The Zionist Archives in Jerusalem. The original archival papers-or what was rescued and located in reasonable shape-were the subjects of a long term study-sponsored by the Romanian government-and in 2010 published as "The working papers in Romanian minority studies, No. 25" authored by Gido Attila and Solyom Szuzsa under the title of "Kolozsvar Nagykarly es Nagyvaradi Zsido Tuleloi. A Zsido Vilagkongreszus 1946-os Eszak Erdely Felmerese." ${ }^{31}$ This nearly 200-page report will be discussed in the subsequent paragraphs. In addition, an overview of the postwar situation is framed from what is known as the "Black Book" of The Holocaust in Romania Facts and Documents, ${ }^{32}$ written by Matatias Carp, it is a four volume work-the last or fourth volume dealing solely with Transylvania- published immediately after the end of the war during the period from 1946-1948. In these documents there is special attention given to the many post-war criminal trials and extensive testimony transcripts provide details. After the fall of Communism in 1989, the successive governments sought to rectify the obliteration of Holocaust memory prevalent in preceding years and a commission was created to organize and document the past. The result was the Nov.11, 2004 Final Report of the Commission on the Holocaust in Romania. ${ }^{33}$ In its introduction we have these details, "On the initiative of Mr. Ion Iliescu, President of Romania, the International Commission on the Holocaust in Romania was established on October 22, 2003. The Commission was conceived from the very beginning as an independent research body, free of any influence and political consideration. The Commission's budget and composition were approved under Government Decision no. 227 of February 20, 2004, and no. 672 of May 5, 2004, respectively. At the invitation of the President of Romania, Mr. Elie Wiesel, Nobel Peace Prize laureate and honorary member of the Romanian Academy, accepted the chairmanship of the Commission." During the production of this work, the Romanian National Archives were also updated and reorganized, with the final result producing a well-indexed file system for studying the Holocaust in Romania. ${ }^{34}$ Detailed reports may be obtained for small localities and for many individuals. These new documents along with the older and previously mentioned ones, allow for some answers to be formulated regarding the research question of "what happened to the Jews"?

\footnotetext{
27 (Stark 1995); (Stark 2000, pp. 19-23)

28 (Mayer 2014)

29 (Stark 2000, p. 23; 31); (Stark and Molin 1995)

30 (Gidó and Sólyom 2010, pp. 7, 8 and 9-16)

31 (Gidó and Sólyom 2010, pasim)

32 (Carp 1994) This 1994 publication is mostly a reprint of the original version, with some of the volumes and pages rearranged.

33 (Commision 2004)

34 (ARHIVA 2014) These file from the Romanian National Archives have now been rearranged according to regionally oriented systems that allow for following the Holocaust in a comprehensive manner.
} 


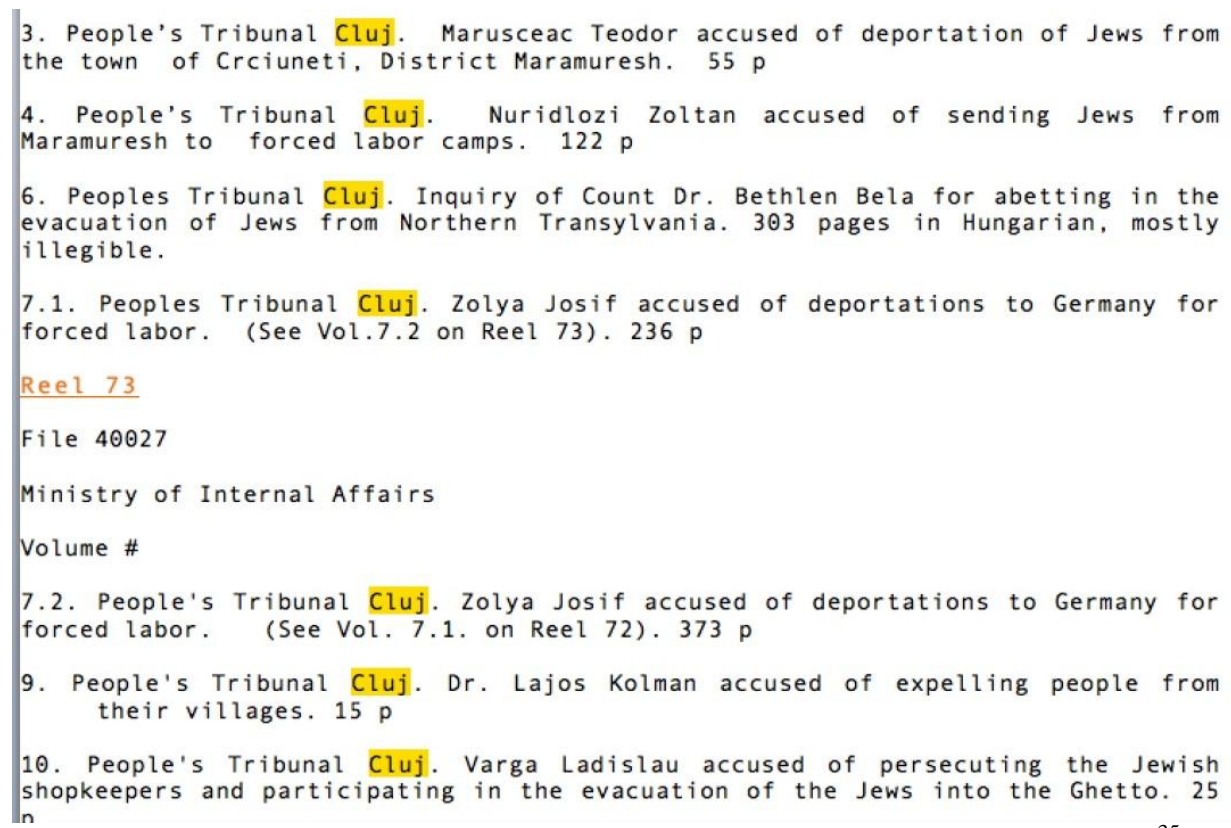

Sample page from ARHIVA files located in Cluj, detailing the Holocaust ${ }^{35}$

On October 11, 1944 Soviet and Romanian troops entered Cluj and during the first week about 80-100 Jews came out of hiding and identified themselves. However, the numbers began to change quite rapidly. When the 1946 WJC files were looked at, it became evident that there were documents and questionnaires covering a span of time from the start of 1945 until sometime in late 1947. These surveys were intended to document current living conditions and needs, but in the recording of material loss a great deal of information was provided by families and friends of non-returning individuals and at times about individuals who had returned but did not volunteer to be surveyed. Thus, counting Jews was nearly impossible with any degree of certainty. The total number of Jewish survivors varied over time with the maximum being recorded as living in Transylvania in April 1947 of 47,927. However, when they looked at the rapid increase in population curves commencing in 1945, but at the same time an increasing rate of emigration to Palestine starting towards the end of 1944, reconciling true numbers for survivorship was impossible. During 1945 the researchers saw the greatest numbers returning to their home residences prior to the war, after which they appeared to start moving away, either inside Romania or Palestine and foreign lands. Simply put, the population numbers at any given time may or may not have the same individual membership as in a previous or later time. For Cluj, the maximum number of Jews seemed to hover around 6000 during the mid-1940s. ${ }^{36}$ To further complicate data gathering, even while some Jews were leaving the area, or the country, although others were still trickling in from captivity as a result of being in the Forced Labor Corps. The same records show that a delegation led by Erno Marton during November 1944 and commissioned by the International Red Cross in Bucharest and the Jewish Agency through the Joint Distribution Committee estimated the total number of Jews in Transylvania to be 7,200. A paltry number? Sure, but this was only a handful of days after the Red Army liberated Cluj. The subsequent weeks and months would see rapid and fluent population flows.

Of even greater implication is the fact that counting populations was also complicated by the changing of territories between states, with Transylvania returning to Romania. Accounting for individuals was also hampered by the frequent changing of names from Hungarian to a Romanianized version. Notwithstanding these small numbers listed above, according to the final data submitted by the WJC in 1947 the population of registered Jews in Romania totaled $428,312 .{ }^{37}$

It becomes obvious that there had to be an incentive for a person to present for a questionnaire or to volunteer information. Possibly and briefly during the first post war months food and financial relief provided by some of the relief organizations may have been one incentive and we take note that the education system briefly-during 6-8 months of 1946-opened its doors to Jewish survivors. Simply put, "many victims of the Holocaust were not ready, however, to have themselves included in yet another list, even if it held out the possibility of receiving some kind of compensation." 38 Perhaps the greatest factor as far as stepping forward might be found in the fact that during the spring

\footnotetext{
${ }^{35}$ Ibid

${ }^{36}$ (Gidó and Sólyom 2010, pp. 40-81).

${ }^{37}$ ((AICE) 2014)

${ }^{38}$ (Stark 2000, p. 3)
} 
of 1946 Cluj was the seat of one of the two courts set up in Romania for wartime trials. Known as the "The Romanian People's Tribunals" and set forth by Law No. 312, issued by the Ministry of Justice on April 21, 1945, the actual trials were held from March to May $1946 .{ }^{39}$ Of the two courthouse seats, one in Bucharest and one in Cluj-covering the Holocaust in Transylvania-the latter was the largest and most significant, perhaps attested to by the number of convictions, which were 481 in Cluj and 142 in Bucharest. These events received much coverage and brought wartime injustices to the forefront of the public theater.

\section{Geopolitical Factors After into War and Post-Holocaust}

Bluntly stated, there were two overarching issues, which would affect everything that would happen to Jews in a post war era. They are the reversion of Transylvania to Romanian governance and the implementation of a Communist regime. According to Holly Case the Transylvania Question was-and to a degree still is-the dominant issue in the national discourses of Hungary and Romania, and since Romania was the post-war victor, whatever befell Transylvania and thus also the Jews was affected by this nationalistic element. ${ }^{40}$ The institution of Romanian governance had two distinct phases in Transylvania. The first phase ensued immediately at the end of the war, "Shortly after the Romanian and Soviet armies had taken Northern Transylvania, a provisional Soviet administration was installed that lasted from mid-November 1944 until mid-March the following year. The fate of the province remained uncertain during that time, and consequently it experienced a kind of de facto autonomy."

Underlining this confusion, "The general befuddlement was such that one Romanian official reported at the end of December that "Northern Transylvania currently does not belong to either Hungary or Romania." 42 However from that point on especially from 1946 to 1948 the Romanian and Communist regime became well established and during these times the ethnic minorities, be they Hungarian or Jewish, found a safety net through joining the Communist party.

For Jews this was not a far-reaching or unusual move because large numbers had already ascribed to a Zionist socialist ideology. Viewed from below, as it were, we have the written observations by a young Jew in his early 30s in Dr.Mozes Carmilly-Weinberger's book. ${ }^{43}$ Weiss Ignac's first recorded observation, written in October 1944, show that during the first few weeks the few young Jews in Cluj, preferred to hang out or play ball in the Romanian neighborhoods over the Hungarian ones. Later he writes that through official support and the efforts of the Neolog Jewish community, the Jewish Hospital was sufficiently renovated to become fully functional by early 1945. Again with the Neologue community leading the efforts, the Jewish schools were slowly brought to functional capacity and on September 1, 1946 the Jewish Gymnasium opened its doors. In this effort to open the gymnasium, Weiss Ignac specifically describes help, both economic and instructional, as being derived from the efforts of ORT, which was headquartered in Bucharest. ${ }^{44}$ Realities of life soon revealed that in order to succeed in the new Communist world, one had to choose sides. The Zionist Socialists were seen as an aberration to Communist life and soon the pro-Communist Jews came together and formed the Jewish Democratic Committee (CDE) and by 1948-1949 they were violently clashing with Zionist groups. Indeed, Zionism was outlawed in Romania in 1949. On the other hand, for a Communist Jew, anything was possible and the life of Ana Pauker is the proof. Born in 1893 as Hannah Rabinsohn into an Orthodox Jewish family whose household head was a ritual slaughterer named Hersh Kaufman Rabinsohn, she very early identified with Bolshevism and was one of the leaders of the Romanian Communist Party during the 1940s until early 1950s.

\footnotetext{
39 (Braham 2012, pp. 48-66)

${ }^{40}$ (Case 2009, pp. 216-224)

41 Ibid p.201

42 Ibid p. 202

43 (Carmilly-Weinberger 1988, pp. 249-256)

44 (O.R.T. 1946); World ORT is one of the oldest and still very active organizations in World Jewry today, predominantly focused on education. Founded in 1909 in Russia-which is where the acronym ORT originated as an abbreviation; its original functions were to assist the development of skilled labor by Jews. Internationalizing rapidly, it was soon active in many countries with regionally autonomous activities characterizing its operation. Shortly after the war ORT was extremely active in DP camps and has, over its long functioning existences assisted an enormous amount of individuals and organizations.
} 


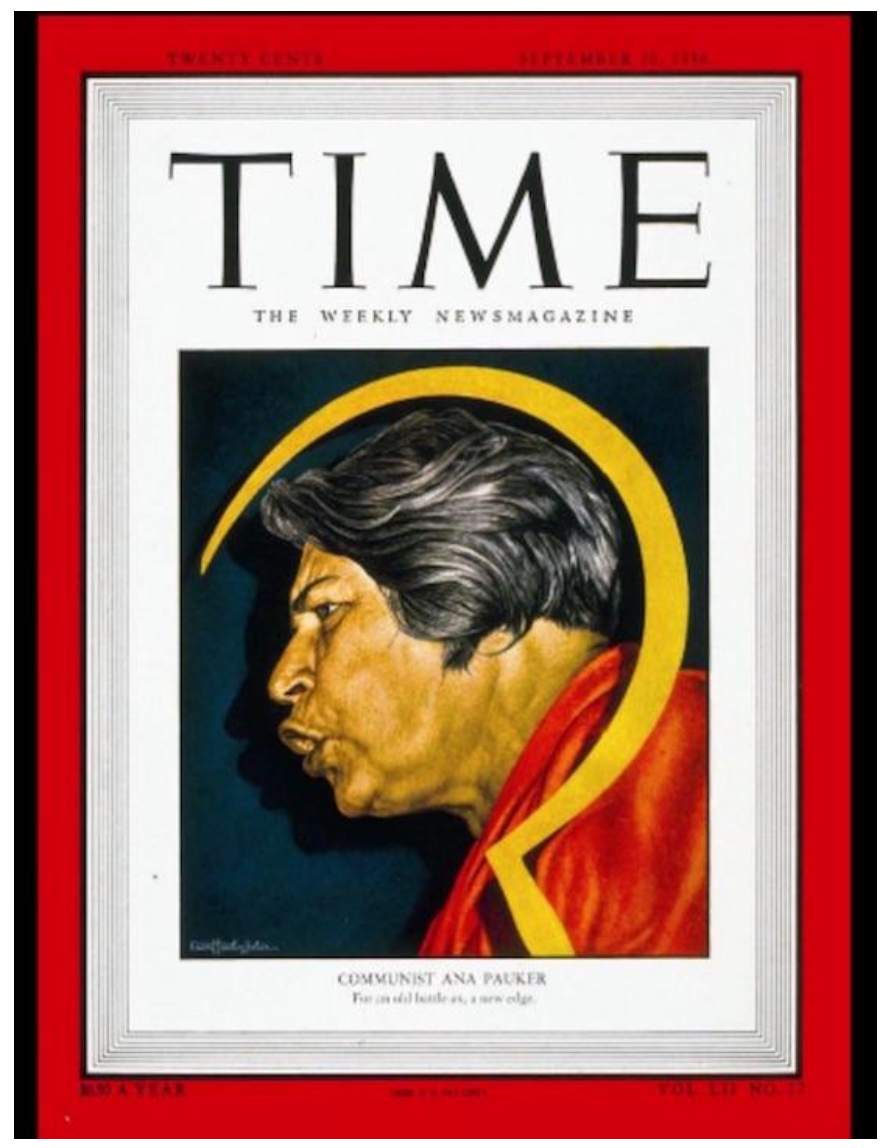

Sept 24, 1948 Time Magazine Cover: Ana Pauker, Communist leader

So strongly was Ana Pauker identified with Communism that she would grace the cover of Time magazine in September 1948. However, by the mid-1950s Stalinism began to exert a very antisemitic message and indeed Ana Pauker became involved in her own controversies becoming suspected by the Moscow led faction in the Communist regime. As a last point, it should be noted that during 1950 she is credited with aiding the emigration of 100,000 Jews to Israel. ${ }^{45}$

While some of the above is critical in the overall conversation about Jews in Romania, it is also reflected in the microcosm of Jewish life in Cluj. The city held as many as 20,000 Jews (highest estimates) in the early 1940s and when the Nazis invaded it held an oppressed but still vibrant Jewish community. So effective were the efforts to deport all that there were virtually no known Jews in Cluj in the summer of 1944. Dr. Carmilly-Weinberger recalls several conversations that July with Erno Marton, located in Bucharest at the time, where they would repeat to each other "there is no Jews left in Kolozsvar." ${ }^{46}$ According to reports when the Soviet and Romanian troops entered Cluj in October, 1944 there were approximately 300 Jews who came out and identified themselves. ${ }^{47}$ Then, by $1946-47$, which is likely to be the zenith of the Jewish population numbers in Cluj, there are over 6,500 Jews living inside the city. As Communism began to take hold over Romania along with Cluj, it became evident that waiting in the wings were long-term socialist activists, many of them from Jewish backgrounds. Indeed, Cluj goes a long way back in the history of Communism and Socialism commencing in the earliest part of the $20^{\text {th }}$ century. Bela Kun, who was arguably the best known and controversial Communist figure in Hungary, began his socialist affiliations in Cluj. Born Bela Kohn, in a Transylvanian village outside of Koloszvar. Kohn graduated from what was then the University of Kolozsvar in 1904, at which time he de-Judaized his name to Kun. He would go on to be the founder of the Hungarian Communist Party, and its leader during the 133 days of Soviet Socialist rule in Hungary in 1919. Following that he would remain a key political and organizational operative of Lenin throughout Europe. He continued to maintain strong contact with the Socialist party in Cluj and it is from this cadre of comrades that the subsequent Communist leaders and politicians came

\footnotetext{
45 (Levy 1995, pasim)

46 (Carmilly-Weinberger 1988, p. 229)

47 (Oltean 2014); (Mayer 2014)
} 
from. ${ }^{48}$ While it took until the 1947 Treaty of Paris to officially return Cluj and Transylvania to Romania, it was during the first few months of 1946 that the greatest shifts in political alignment took hold. This began with a series of violent demonstrations by college students of Romanian heritage who were now returning to Cluj and were opposed to the Hungarian influences still entrenched in the city. For the Jews this period during 1946 became a decisive factor in choosing to remain and partake in a Communist enterprise, or to emigrate, usually to Palestine but to the USA as well. During this time period the majority of Jews chose a mass exit from Cluj, as well as the rest of Romania. ${ }^{49}$

\section{Observations}

To begin with it has been clear through the years that the survivor group has included a disproportionately larger percent of those who had held economic, religious, or political advantage. These individuals were saved prior to deportation and the majority would wind up in Israel, and smaller numbers in the US. None would return to Cluj (or Romania).

To create a comprehensive and accurate picture of what happened immediately after the end of WWII is difficult because of the surreptitious maneuverings involved in carrying out each person's path. Individuals were clinging to survival after great losses and sought out any means possible, which was often fulfilled by altering identity and identification. It is poignant to recall that population tallies conducted in the months after the liberation of Cluj would frequently include different individuals than similar population counts a few months earlier, or later; the headcount may be similar but the heads were shifting.

Simply put, the answer to what happened after the end of WWII and the Holocaust to the Jews of Transylvania and in Cluj, is that they left, disappeared, vacated the region.

Indeed, if one looks at the populations, Romania proper during the 1940s had a Jewish population between 700,000-800, 00; in Transylvania or what would be accounted for in a Hungarian population during this time we have close to 160,000 Jews. This number is close to a million, yet today the number of Jews in Romania is less than $10,000 !^{50}$ What can explain this has been the main focus of this work. Clearly, the upheavals in population were a direct result of the Holocaust. What remains less clear, or more complex, are the various forces that came to bear on such drastic changes. While the formation of the State of Israel in 1948 finally provided a national homeland for Jews for the first time in modern history, immediately after the war Eretz Israel was still in Palestine, a British territory. Surely, the lands had a strong appeal, founded in Zionism, but now there were newly found longings for these principles as a result of the Holocaust. However, this examination has determined that the predominant influences may be attributed to the social, political and geographic upheavals taking place in Transylvania, including Cluj, which were particular and specific because of the nature of localized history. Cluj Jews had to contend with the destruction and loss they suffered during the Holocaust and afterwards with an uncertain future in a city where previous generations thrived and flourished. The installation of Communism had perhaps the greatest influence and as we have noted, even the smaller number of Jews who initially embraced this change soon found their fortunes changing rapidly. Changes in national governance and the consequent cultural, linguistic and political atmosphere exerted a strong influence, but on the other hand, they had already seen this once before. Quite simply the Jews in Cluj were not only caught "between states" as Holly Case puts it, but also "between states of mind" with the consequences being life or death.

\section{References}

ARHIVA. (2014). Selected Records:Romanian National Archives (Cluj barnch) relating to Holocaust in Romania. Cluj and Bucharest Romania: ARHIVA.

Bauer, Y. (1994). Jews for sale? : Nazi-Jewish negotiations, 1933-1945. New Haven: Yale University Press.

Blumstock, R., \& Braham, R. L. (1981). The Politics of Genocide: The Holocaust in Hungary. JSTOR.

Braham, R. L. (2012). Genocide and Retribution: Springer Science \& Business Media.

Braham, R. L. (1981). New York: Columbia University Press. The politics of genocide : the Holocaust in Hungary. 2(1).

Braham, R. L. (1983). Genocide and retribution : the Holocaust in Hungarian-ruled northern Transylvania, East European monographs Holocaust studies series. Boston Hingham, Ma.: Kluwer-Nijhoff, Distributors for North America, Kluwer Boston.

Braham, R. L. (1994). The politics of genocide : the Holocaust in Hungary. Rev. East European monographs. New York

48 (Lőwy and Lőwy 2005, pp. 85-95)

49 (Gidó 2010, pp. 116-143)

50 (DellaPergola 2013); (Mayer 2015) 
Bruszt, L., \& George, K. H. (1990). 1989: the negotiated revolution in Hungary. Social Research, 365-387.

Carmilly-Weinbereger, M. (1970). Memorial Volume for the Jews of Kolozsvar A Kolozsvari Zsidosag Emlekkonyve. New York: Shhulsinger Bros.

Carmilly-Weinberger, M. (1988). A kolozsvári zsidóság emlékkönyve: Sepher-Hermon Press.

Carp, M. (1994). Holocaust in Rumania: facts and documents on the annihilation of Rumania's Jews, 1940-44: Primor Publishing.

Case, H. (2009). Between states : the Transylvanian question and the European idea during World War II. Stanford, Calif.: Stanford University Press.

Cohen, A. (1986). The Halutz Resistance in Hungary, 1942-1944, East European monographs. Boulder Colo. New York: Social Science Monographs ;

Institute for Holocaust Studies of the City University of New York : Distributed by Columbia University Press.

Commision, Romanian International Comission Holocaust. (2004). Final Report on Holocaust in Romania. In Report on Holocaust in Romania, edited by Romanian and International Commision on Holocaust. Bucharest, Romania: Commisioned by the President of Romania.

Deletant, D. J. (2006). Hitler's Forgotten Ally. Ion Antonescu and his regime, Romania 1940-1944.

DellaPergola, S. (2013). World Jewish Population, 2012. In American Jewish Year Book 2012, 213-283. Springer.

Fenyo, M. (2014). Jews in Budapest during 1944-1945.

Gidó, A. (2010). A holokauszt mérlege. 1946-os helyzetkép az észak-erdélyi zsidóságról. Regio, 3, $116-147$.

Gidó, A., \& Zsuzsa, S. (2010). The Surviving Jewish Inhabitants of Cluj, Carei and Oradea. The Survey of the World Jewish Congress in 1946. Working Papers in Romanian Minority Studies.

Herzberger, M. (2013 \& 2014). Herzberger Interview. edited by Gabriel Mayer.

H.E.A.R.T. Holocaust Reserch Project. (2013). Blood for Goods. In Holocaust Education Archives Research Team.

Herzberger, M. (2005). Survival. Austin, Texas: Groundbreaking Press.

Herzberger, M. (2011). Transcript of 1980 Magda Herzberger Interview by the Wisconsin Historical Society. Edited by Barbara Foley. Austin, Tx: Groundbreaking Press.

Kasztner, R. (2013). The Kasztner Report. Jerusalem: Yad Vashem.

Lustigs. (2014-2016). Interviews Lustigs: Hava, Joseph, Ron. Safed, Israel.

Levi, P. (1996). Survival in Auschwitz: Simon and Schuster.

Levy, R. (1995). The Right Deviation of Ana Pauker. Communist and Post-Communist Studies, 28(2), $239-254$.

Levy, R. (2001). Ana Pauker: the rise and fall of a Jewish Communist: Univ of California Press.

Lőwy, D., \& Dániel, L. (2005). A Kálváriától a tragédiáig : Kolozsvár zsidó lakosságának története. 2., jelentősen bőv.' es átdolg. kiad. ed. Kolozsvár: Koinónia.

Lőwy, D., \& Réka, S. (1998). A téglagyártól a tehervonatig : Kolozsvár zsidó lakosságának története. Kolozsvár: Erdélyi Szépmíves Céh.

Mayer, P. (2013). Mayer, Peter Interview. edited by Gabriel Mayer.

Mehadea, A. (1991). Interview: Mehadea, Andres. edited by G. Mayer.

Mayer, G., \& Dascultu, I. (2015). Where are the Jews in post-Holocaust, post-Commuinst Romania? Conference of the Society for Romanian Studies, Bucharest, Romania, 15-19,

Mayer, G. (2014). Holocaust in Kolozsvar: 1944. International Journal of Social Science Studies, 2(3), 100-108.

Nussbacher, M. (2014). Interview Nussbacher. edited by G; Mayer.

O. R. T., World. (1946). The Work of the O.R.T. in Europe. Paris, France.

Oltean, A. (2014). ONGOING THEORY-DRIVEN EVALUATION OF THE PUBLICATIONS FROM ROMANIA AND HUNGARY CONCERNING THE HISTORY OF THE JEWS FROM ROMANIA AND HUNGARY DURING THE. Analele Universităţii din Oradea. Relaţii Internationale şi Studii Europene (RISE) (VI), 71-84.

Pop, G. (2008). The Dr Moshe Carmilly Institute for Hebrew and Jewish History and the Library of Jewish Studies. Philobiblon: Transylvanian Journal of Multidisciplinary Research in Humanities, 13. 
Roth, P. (1980). Primo Levi Interviews. In Web of Stories, edited by Web of Stories: Internet based Multimedia.

Stark, T. (1995). Zsido\0301sa\0301g a ve\0301szkorszakban e\0301s a felszabadula\0301s uta\0301n (1939-1955). Budapest: MTA Tol0308rtel0301nettudomal0301nyi Intel0301zet.

Stark, T. (2000). Hungarian Jews during the Holocaust and after the Second World War, 1939-1949 : a statistical review. Boulder: East European Monographs.

Stark, T., \& Karl, M. (1995). Hungary's human losses in World War II: Uppsala.

Strochlitz, Strochlitz Institute Archives. (1943-1949). Hungarian Romanian Archives Holocaust. Guide No. 4 R1-4C; and Box 42 (AICE), Virtual Jewish World: American-Israeli Cooperative Enterprise. 2014. Jewish Romania. American-Israeli Cooperative Enterprise (AICE). http://www.jewishvirtuallibrary.org/jsource/vjw/romania.html.

Vrba, R., \& Alan, B. (1964). I cannot forgive. New York: Grove Press.

\section{(cc) BY}

This work is licensed under a Creative Commons Attribution 3.0 License. 